\title{
Gel Strength of Kamaboko Gels Produced by Microwave Heating
}

\author{
Weijie MaO ${ }^{1}$, Mika FukUoka ${ }^{2}$ and Noboru SAKAI ${ }^{2 *}$ \\ ${ }^{1}$ College of Life Science, Dalian Nationalities University, Economic and Technological Development District, Dalian 116600, China \\ ${ }^{2}$ Department of Food Science and Technology, Tokyo University of Marine Science and Technology, Minato-ku, Tokyo 108-8477, Japan
}

Received February 20, 2006; Accepted September 3, 2006

\begin{abstract}
In this study, the strength of kamaboko gels heated by microwaves was investigated, and the change of elasticity of kamaboko gel during microwave heating was determined. The strength of gels made under direct microwave heating was low; therefore, a new method using microwaves to set and to cook the gels was developed. It was found that the strength of two-step gels prepared by microwave heating had a value similar to gels heated using a water bath. Moreover, setting and cooking the gels using microwave heating took 11 minutes, which constituted an $80 \%$ reduction in production time compared to the boiling method.
\end{abstract}

Keywords: kamaboko, microwave heating, gel strength

\section{Introduction}

Kamaboko is a traditional Japanese food. Since it is made from highest quality fresh fish and is rich in protein and low in calories and fat, kamaboko is quickly becoming a popular health food worldwide.

In order to manufacture kamaboko, raw or frozen surimi is ground with salt and other ingredients, then extruded, molded, and finally heated (Okada, 1992). One of the most important processing stages is heating; the heating temperature and the rate of heating determine the kamaboko's quality (Yongsawatdigul and Park 1996; Yamazawa, 1990). The elastic quality of kamaboko is called "ashi" in Japanese, and "ashi" is an important parameter for evaluating the quality of kamaboko. It varies according to many factors, such as the species and the freshness of fish used and processing techniques (Okada, 2000). It is commonly known that the surimi from some fish species has the unique ability to form translucent, elastic gels below $40^{\circ} \mathrm{C}$ after being ground with salt. This ability is called setting (suwari) and it improves the quality of "ashi" (Niwa et al., 1991). Consequently, a two-step heating procedure is widely used; specifically, a salt-solubilised myofibrillar protein (sol) is set at a temperature below $40^{\circ} \mathrm{C}$ to produce translucent gels (suwari type), with the second step consisting of heating at a temperature above $80^{\circ} \mathrm{C}$ to produce opaque, highly elastic kamaboko-type gels (Alvarez et al., 1995). However, because the traditional setting method requires fine temperature management over a long period and the labor of many people, it is not suitable for mass production. Therefore, since the 1970s, microwave heating has been considered a very promising heating method in the kamaboko production process. Microwave heating is based on a material's ability to absorb electromagnetic

* To whom correspondence should be addressed.

E-mail: sakai@kaiyodai.ac.jp radiation energy and to convert it to heat, with rapid heating occurring effectively from the inside. Therefore, for food processing, the use of microwave heating is faster, cheaper, and requires less labor than other sources of heat, making continuous processing possible. Davidovich and Pigott (1982) carried out sensory testing to determine the texture of kamaboko produced by microwave heating and showed that the texture characteristics were similar to those heated by traditional means. Yamaguchi (1982) developed a manufacturing process of deep-fat boiled kamaboko that incorporated a microwave heating device in the production line. The improved efficiency resulting from the drastic shortening of the setting (suwari) time by microwave heating promises to provide great economic benefits. However, until now it has been used mainly as the preliminary heating method in a two-step heating process, since direct microwave heating results in inferior kamaboko. Therefore, a method is anticipated that can make continuous processing of kamaboko possible using the microwave heating to set and to cook. In addition, the quality of kamaboko produced by microwave heating has not been clarified yet. Thus, the aim of the present work is to investigate the change in rheological properties of kamaboko gel prepared by microwave heating.

\section{Materials and Methods}

Gel Preparation Frozen Alaska pollock surimi (SA grade, Alaska Co., Ltd.) was used. The water content of the surimi was $77.2 \%$. The frozen surimi was thawed at $4-7^{\circ} \mathrm{C}$ for $12 \mathrm{hr}$. All sample preparations were carried out at $5-10^{\circ} \mathrm{C}$. The thawed surimi $(661 \mathrm{~g})$ was cut into small pieces and then ground in a food processor for $2 \mathrm{~min}$. Salt $(20 \mathrm{~g})$ was added to surimi, and the mix chopped for 3 min to form a paste. Then $50 \mathrm{~g}$ potato starch and $269 \mathrm{~g}$ water were added to the salted surimi paste, and this was ground for $3 \mathrm{~min}$. The final moisture was adjusted to 
(1)

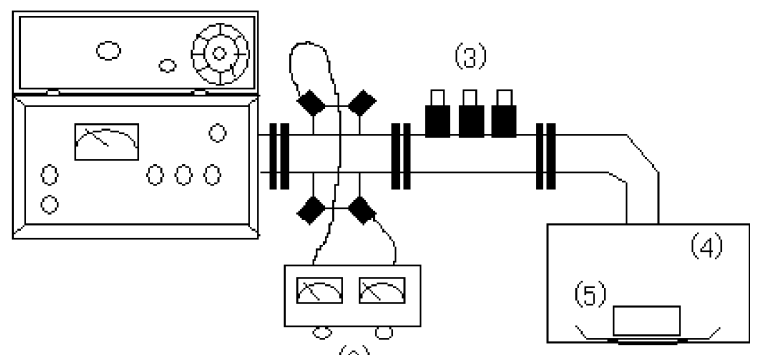

(2)

Fig. 1. Microwave heating system. (1) Microwave generator, (2) power monitor, (3) matched load, (4) cavity, (5) sample.

$78 \%$. The surimi paste was packed into polyvinyl chloride mini cups $\left(3.3 \times 10^{-2} \mathrm{~m}\right.$ inner diameter, $3.5 \times 10^{-2} \mathrm{~m}$ height) by a $3-1$ capacity sausage filler (CSC-02, F.A.C.E.M. Spa, Turin, Italy) and the samples were wrapped in thin plastic film, and then stored in an icebox until use.

Some samples whose center temperature was measured using a fiber optic thermometer probe (F1000-2S, Anritsu Meter Co., Ltd, Tokyo, Japan), were heated using microwave system, as shown in Fig. 1. The system consisted of:

1) A microwave generator (TMG131, Toshiba Co., Ltd, Tokyo, Japan).

2) Two power monitors. These were used to measure the forward and backward microwave power to/from the power generator/cavity (TMU 906A, Toshiba Co., Ltd, Tokyo, Japan).

3) An impedance matching unit to adjust the reflection microwave power to the smallest level (TMU-224A, Toshiba Co., Ltd, Tokyo, Japan).

4) Cavity

The output power was $300 \mathrm{~W}$. For one-step heating, the sample was heated directly until its center temperature reached $90^{\circ} \mathrm{C}$. When the center temperature reached $90^{\circ} \mathrm{C}$, some samples were further intermittently heated to maintain their center temperature at $90^{\circ} \mathrm{C}$ for 3 min or for 5 min, as shown in Fig. 2. According to a study performed by Toishi and Muranaka (1982), samples set for a short time by microwave heating had the same quality as those set for a long time using the traditional method. Consequently, for two-step heating the setting conditions by microwave of $30^{\circ} \mathrm{C}$ for $4 \mathrm{~min}$ (Fig. 3), or $40^{\circ} \mathrm{C}$ for 3 min were chosen by us. Moreover, in order to compare with microwave heating, some samples whose center temperatures were measured using a thermocouple were heated by $90^{\circ} \mathrm{C}$ water-bath (T205, Thomas Kagaku Co., Ltd, Tokyo, Japan); when their center temperatures reached $90^{\circ} \mathrm{C}$, these samples were further heated for $5 \mathrm{~min}$. Furthermore, for two-step heating, the sample was set in a $30^{\circ} \mathrm{C}$ water bath for 30 min, and then heated in another $90^{\circ} \mathrm{C}$ water bath. Each of these heating conditions is shown in Table 1. Heated gels were immediately chilled to below $5^{\circ} \mathrm{C}$ in ice water and stored in an ice box until use. In addition to the above, a commercial kamaboko product (Fukusima, Japan) was used to perform a control experiment.

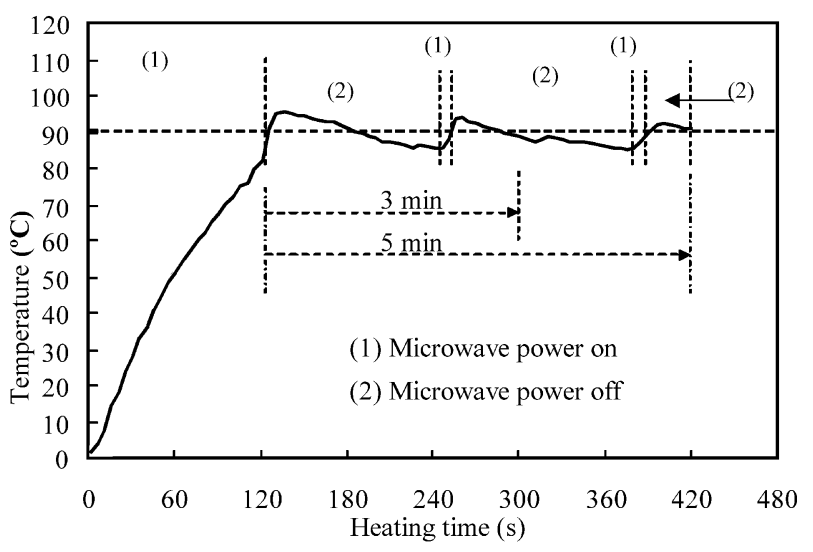

Fig. 2. Heating procedure for one-step microwave heating.

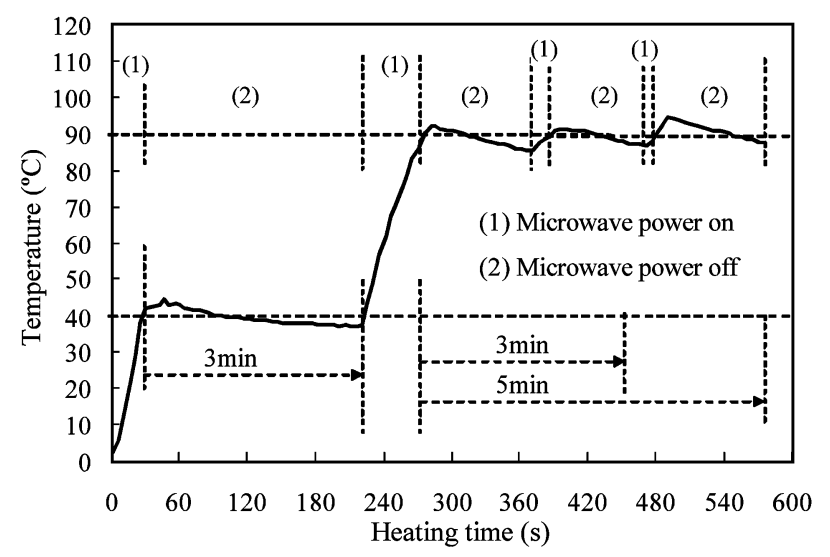

Fig. 3. Heating procedure for two-step microwave heating.

Gel strength test The samples were removed from the mini cups and were cut into so that they were $1.5 \times$ $10^{-2} \mathrm{~m}$ in length and $3.3 \times 10^{-2} \mathrm{~m}$ in diameter using the fixture shown in Fig. 4. The gels were tempered for $3 \mathrm{hr}$ at ambient room temperature $\left(\approx 22^{\circ} \mathrm{C}\right)$ prior to analysis. A punch test was used to evaluate the quality and the gel formation process using a rheometer (3305S, Yamaden Co., Ltd., Tokyo, Japan). The break force (N) and break deformation $(\mathrm{m})$ were measured using the rheometer with a $3 \times 10^{-3} \mathrm{~m}$ diameter plunger, loading perpendicularly on the gels at a loading rate of $1 \times 10^{-3} \mathrm{~m} / \mathrm{s}$. The break strength was calculated by dividing the break force $(\mathrm{N})$ by the area of plunger $\left(\mathrm{m}^{2}\right)$. The gel strength was determined as the product of break strength and break deformation (Hsu, 1995, Nakamura et al., 1998).

Elasticity test The samples whose center temperature reached $50^{\circ} \mathrm{C}, 60^{\circ} \mathrm{C}, 70^{\circ} \mathrm{C}, 80^{\circ} \mathrm{C}, 90^{\circ} \mathrm{C}$, or that were maintained at $90^{\circ} \mathrm{C}$ for $3 \mathrm{~min}$ or $5 \mathrm{~min}$, were prepared for evaluating the gel formation process. Gels that were not heated sufficiently were hard to break. The change in the gel's elasticity during heating was evaluated. The sample was cut into lengths of $1 \times 10^{-2} \mathrm{~m}$ as shown in Fig. 4 , and sections were cut out using a $2.1 \times 10^{-2} \mathrm{~m}$ cork borer. The gels were compressed using the rheometer with a $5 \times$ $10^{-3} \mathrm{~m}$ diameter cylindrical plunger at a loading rate of 1 $\times 10^{-3} \mathrm{~m} / \mathrm{s}$. The change in the force with time was 
Table 1. Heating methods for prepared kamaboko gel.

\begin{tabular}{|c|c|c|}
\hline Heating method & Microwave & Water bath \\
\hline $\begin{array}{l}\text { One-step heating (without } \\
\text { setting process) }\end{array}$ & $90^{\circ} \mathrm{C}, 90^{\circ} \mathrm{C} 3 \mathrm{~min}, 90^{\circ} \mathrm{C} 5 \mathrm{~min}$ & $90^{\circ} \mathrm{C} 5 \mathrm{~min}$ \\
\hline \multirow{3}{*}{$\begin{array}{l}\text { Two-step heating for } \\
\text { gel strength experiment }\end{array}$} & $\begin{array}{l}\text { Setting at } 30^{\circ} \mathrm{C} \text { for } 4 \mathrm{~min} \\
\text { then heating to } 90^{\circ} \mathrm{C}, 90^{\circ} \mathrm{C} 3 \mathrm{~min} \text {, } \\
90^{\circ} \mathrm{C} 5 \mathrm{~min}\end{array}$ & $\begin{array}{l}\text { Setting at } 30^{\circ} \mathrm{C} \text { for } 30 \mathrm{~min} \\
\text { then heating to } 90^{\circ} \mathrm{C} 5 \mathrm{~min}\end{array}$ \\
\hline & $\begin{array}{l}\text { Setting at } 40^{\circ} \mathrm{C} \text { for } 3 \mathrm{~min} \\
\text { then heating to } 90^{\circ} \mathrm{C}, 90^{\circ} \mathrm{C} 3 \mathrm{~min} \text {, } \\
90^{\circ} \mathrm{C} 5 \mathrm{~min}\end{array}$ & $\begin{array}{l}\text { Setting at } 40^{\circ} \mathrm{C} \text { for } 30 \mathrm{~min} \\
\text { then heating to } 90^{\circ} \mathrm{C} 5 \mathrm{~min}\end{array}$ \\
\hline & $\begin{array}{l}\text { Setting at } 4-7^{\circ} \mathrm{C} \text { for } 12 \mathrm{hr} \\
\text { then heating to } 90^{\circ} \mathrm{C}, 90^{\circ} \mathrm{C} 3 \mathrm{~min} \text {, } \\
90^{\circ} \mathrm{C} 5 \mathrm{~min}\end{array}$ & $\begin{array}{l}\text { Setting at } 4-7^{\circ} \mathrm{C} \text { for } 12 \mathrm{hr} \\
\text { then heating to } 90^{\circ} \mathrm{C} 5 \mathrm{~min}\end{array}$ \\
\hline $\begin{array}{l}\text { Two-step heating for } \\
\text { elasticity test experiment }\end{array}$ & $\begin{array}{l}\text { Setting at } 40^{\circ} \mathrm{C} \text { for } 3 \mathrm{~min} \\
\text { then heating to } 50^{\circ} \mathrm{C}, 60^{\circ} \mathrm{C}, 70^{\circ} \mathrm{C}, \\
80^{\circ} \mathrm{C}, 90^{\circ} \mathrm{C}, 90^{\circ} \mathrm{C} 3 \mathrm{~min}, 90^{\circ} \mathrm{C} 5 \\
\text { min }\end{array}$ & $\begin{array}{l}\text { Setting at } 30^{\circ} \mathrm{C} \text { for } 30 \mathrm{~min} \\
\text { then heating to } 50^{\circ} \mathrm{C}, 60^{\circ} \mathrm{C} \text {, } \\
70^{\circ} \mathrm{C}, 80^{\circ} \mathrm{C}, 90^{\circ} \mathrm{C}, 90^{\circ} \mathrm{C} 5 \mathrm{~min}\end{array}$ \\
\hline
\end{tabular}

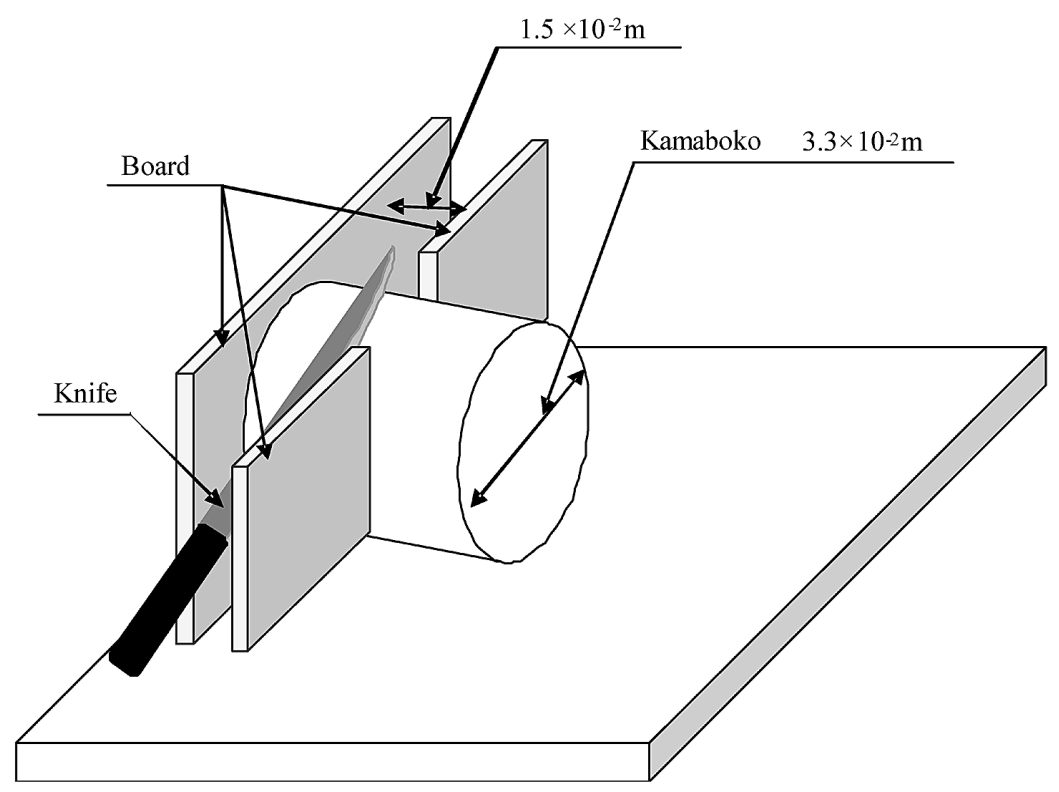

Fig. 4. Schematic diagram of cutting fixture.

recorded by computer. The deformation was calculated by multiplying the time by the loading rate. The stress was calculated by dividing the force $(\mathrm{N})$ by the area of the plunger $\left(\mathrm{m}^{2}\right)$, and the strain was expressed as the ratio of the compression distance and the original height (Fig. 5). According to Fig. 5, the stress-strain curve was almost linear when the strain was between 0 and 0.5 ; at these strains the gel can be considered an elastic body. The elasticity $\left(\mathrm{N} / \mathrm{m}^{2}\right)$ was calculated by dividing the stress by the strain of 0.5 .

All determinations were performed at least six times.

\section{Results and Discussion}

It was observed that the gel strength of the one-step heated gel was very low. In particular, the strength of gels induced by microwave heating was lower than that of gels induced by water-bath heating (Fig. 6 - one-step heating). It is considered that microwave heating caused a sudden rise in temperature, with the sample tempera-



Fig. 5. An example of compressive curve of kamaboko. 




Fig. 6. Gel strength $(\mathrm{N} / \mathrm{m})$ of kamaboko gel after heated by microwave or water bath. ( $\square)$ Gels prepared by water bath heating; (巨) gels prepared by microwave heating (heating stopped when the center temperature of samples reached $90^{\circ} \mathrm{C}$ ); $(\mathbb{Z})$ gels prepared by microwave heating (when the center temperature of samples reached $90^{\circ} \mathrm{C}$, further heated at $90^{\circ} \mathrm{C}$ for $3 \mathrm{~min}$ ); (Ш) gels prepared by microwave heating (when the center temperature of samples reached $90^{\circ} \mathrm{C}$, further heated at $90^{\circ} \mathrm{C}$ for $\left.5 \mathrm{~min}\right)$; ( $)$ gels prepared from commercial products. Vertical lines indicate standard deviation.

tures reaching $90^{\circ} \mathrm{C}$ in only 2 min (Fig. 2). As a result, the heat coagulation of the gels' protein was incomplete. For that reason, as the center temperature reached $90^{\circ} \mathrm{C}$ and the heating time was extended to 3 or $5 \mathrm{~min}$ through intermittent heating, the gel strength of the samples increased gradually. However, the value of the gel strength was still very low. In other words, the quality of gel was inferior, so much so that it was easily crushed between one's fingers; such a gel cannot be called kamaboko. According to Alvarez and Tejada (1997), and Lou et al. (2000), proteins form gel networks through a coordinated transition from denaturation to gelation. When denatured instantly by intense heating, the denatured protein molecules were randomly extended or coiled so that they could not form a cohesive gel matrix system through coordinated interaction, resulting in a low gel strength.

Therefore, a two-step heating method was used. The gel strengths of two-step heated gels were significantly higher than those of one-step heated gels. For example, the gel strength of the gel heated by two-step heating after setting at a low temperature was about $5010 \mathrm{~N} / \mathrm{m}$, about four times larger than that of a one-step heated gel. This indicates that the setting process gives rise to a more evenly dispersed network structure. Therefore, heating of setting gels to produce kamaboko gels causes further aggregation of a structure formed in the setting stage, due probably to large-scale formation of disulfide bridges and hydrophobic interactions at high temperatures (Niwa 1992). As a result, the strength of the gel was greater than when setting was not employed. At the same time, it is generally accepted that the gels set at different temperatures exhibited networks having different characteristics that changed in the transition to kamaboko, improving the texture of the initially formed network. In this study, the strength of gels set at low temperatures $\left(4 \sim 7^{\circ} \mathrm{C}\right)$ had relatively high values, and for high temperature setting the strength of gels set at $30^{\circ} \mathrm{C}$ was higher than that of gels set at $40^{\circ} \mathrm{C}$. However, low temperature setting is not suitable for continuous production because it is time consuming and requires too much space. Therefore, a high temperature setting is needed for continuous mass production.

Moreover, it was found that the gel strengths of gels prepared by microwave at $30^{\circ} \mathrm{C}$ for $4 \mathrm{~min}$ or $40^{\circ} \mathrm{C}$ for $3 \mathrm{~min}$ followed by intermittent heating for $5 \mathrm{~min}$ at $90^{\circ} \mathrm{C}$ were similar to those of gels prepared by water bath and were higher than that of the commercial product (Fig. 6). Consequently, the quality of products can be improved by employing the setting process. At the same time, the production time can be reduced by using microwaves to set and to cook. For example, at $30^{\circ} \mathrm{C}$, setting time was only 4 min. Adding this to the cooking time, gives a production time of about 11 min using microwave heating (Fig. 7(A)), which is $80 \%$ less than that for the boiling method (Fig. 7(B)). Therefore, the method of setting at high temperatures by microwave heating was found to be suitable for mass production.

In addition, there is little information available regarding the changes gels undergo during heating. For this reason, we investigated the shift in the gel's elasticity that occurs in the transition from a setting gel to a kamaboko gel. The changes in the elasticity of gels during microwave heating and during boiling are shown in Figs. 8 and 9 , respectively. During microwave heating, the gels' elasticity increased with heating time. In particular, the elasticity increased remarkably during the first 65 seconds of 



Fig. 7. The time of kamaboko made by microwave heating or water boiling. (A) Microwave heating, (B) Boiling.

heating, when the center temperature increased from $40^{\circ} \mathrm{C}$ at 0 second to $90^{\circ} \mathrm{C}$ at 65 seconds, whereas after this period, the change in elasticity was relatively small. $\quad 50^{\circ} \mathrm{C}-70^{\circ} \mathrm{C}$ is called the temperature range of "modori"; in this temperature range the gel product is easily damaged. This happens when heating is performed at an inappropriately slow rate of temperature increase of the body of surimi paste (Matsumoto and Noguchi, 1992). However, the phenomenon of modori was not observed for microwave heating because of the high heating speed. Conversely, the elasticity of the gel increased rapidly in this temperature range, according to the coagulation of the protein.

During boiling, the elasticity increased dramatically between 150 seconds (center temperature $50^{\circ} \mathrm{C}$ ) to 490 seconds (center temperature $80^{\circ} \mathrm{C}$ ). Here, because the setting temperature and setting time differed, it is thought that the change in the gel's elasticity for the two heating methods cannot be compared directly. However, we can see that the elasticity of the gels prepared by microwave heating changed very rapidly and it took only 360 seconds to reach to its highest value. In contrast, it took about 1300 seconds to reach the highest value using the boiling method.

Therefore, the above results indicate that good kamaboko can be produced more efficiently by utilizing microwave heating, allowing both a shorter production time and continuous mass production. However, according to Shibata et al. (1978) the temperature distribution in kamaboko under microwave heating was non-uniform. Moreover, we have previously reported (2005) that the



Fig. 8. The change of elasticity of gels during microwave heating: $(\boldsymbol{\square})$ elasticity, ( $\boldsymbol{\Delta}$ ) center temperature of sample. Vertical lines indicate standard deviation.

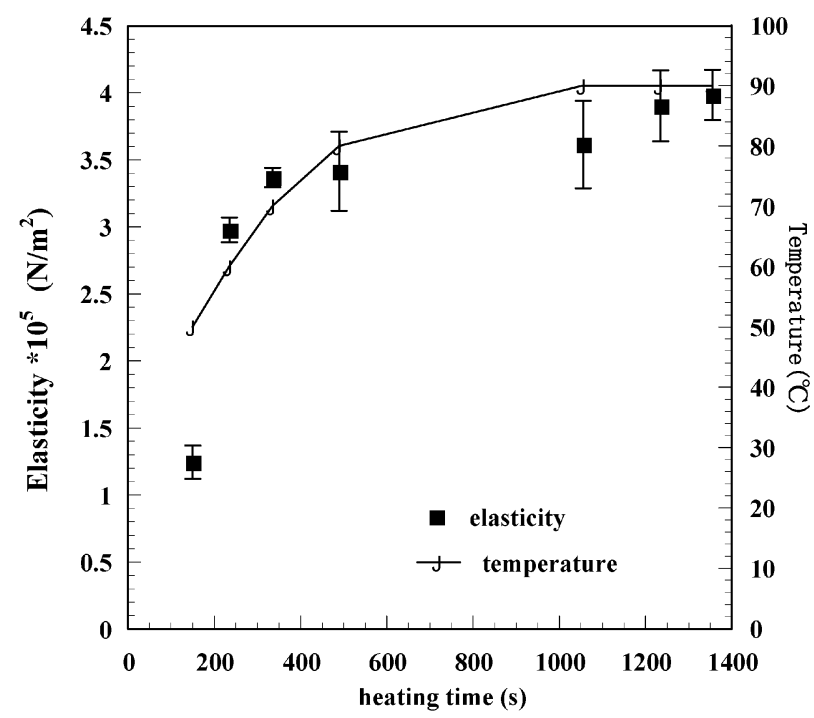

Fig. 9. The change of elasticity of gels during water boiling: ( $\boldsymbol{\square}$ ) elasticity, ( $\boldsymbol{\boldsymbol { \Delta }}$ ) center temperature of sample. Vertical lines indicate standard deviation.

temperature distribution depended on the kamaboko's size and shape. An inhomogeneous temperature distribution may adversely affect product quality. Therefore, our next study will investigate the influence of nonuniform temperature distributions on kamaboko quality in an attempt to determine the optimum conditions of different shaped kamaboko produced by microwave heating.

\section{References}

Alvarez, C., Couso, I. and Tejada, M. (1995). Sardine surimi gels as affected by salt concentration, blending, heat treatment and moisture. J. Food Sci., 60, 622-626.

Alvarez, C. and Tejada, M. (1997). Influence of texture of suwari gels on kamaboko gels made from sardine (sardine pilchardus) 
surimi. J. Sci. Food Agric., 75, 472-480.

Davidovich, L. and Pigott, G.. (1982). The use of microwave power in the fabrication of "kamaboko". J. Microw. Power, 17, 335-340.

Hsu, S.Y. (1995). Optimization of the surimi processing system with a central composite design method. J. Food Eng., 24, 101111.

Lou, X., Wang, C., Xiong, Y.L., Wang, B. and Mims, S.D. (2000). Gelation characteristics of paddlefish (polydon spathula) surimi under different heating conditions. J. Food. Sci., 65, 394398.

Mao, W.J., Watanabe, M. and Sakai, N. (2005). Analysis of temperature distributions in kamaboko during microwave heating. $J$. Food Eng., 71, 187-192.

Matsumoto, J.J. and Noguchi, S.F. (1992). Cryostabilization of protein in surimi. In: surimi technology, eds. Lanier Tc and Lee, C.M. Marcel Dekker, Inc, New York, USA, pp.357-388.

Nakamura, S., Ogawa, M., Sato, M. and Nakai, S. (1998). Application of polymannosylated cystatin to surimi from roe-herring to prevent gel weakening. FEBS Letters., 427, 252-254, 1998.
Niwa, E. (1992). Chemistry of surimi gelation. In: surimi technology, eds. Lanier Tc and Lee, C.M. Marcel Dekker, Inc, New York, USA, pp. 389-428.

Okada, M. (1992). History of surimi technology in Japan. In: Surimi Technology, eds. Lanier Tc and Lee, C.M. Marcel Dekker, Inc, New York, USA, pp. 3-21.

Okada, M. (2000). The science of kamaboko, eds. Okada, M, Seizando, Inc, Tokyo, Japan.

Shibata, C., Akioka, T., Kido, T. and Haneda, H. (1978). Application of microwave on food processing - heating and sterilizing. Food Ind. Center Tech. Res. Rep., 2, 85-95.

Yamaguchi, Z. (1982). About the microwave heating equipment for kamaboko. New Food Ind., 24, 1-5 (in Japanese).

Yamazawa, M. (1990) Effect of hight temperature heating on physical properties of kamaboko-gel, Nippon Suisan Gakkaishi, 56, 497-503.

Yongsawatdigul, J. and Park, J.W. (1996) Linear heating rate affects gelation of Alaska pollock and Pacific whiting surimi, $J$. Food Sci, 61, 149-153. 